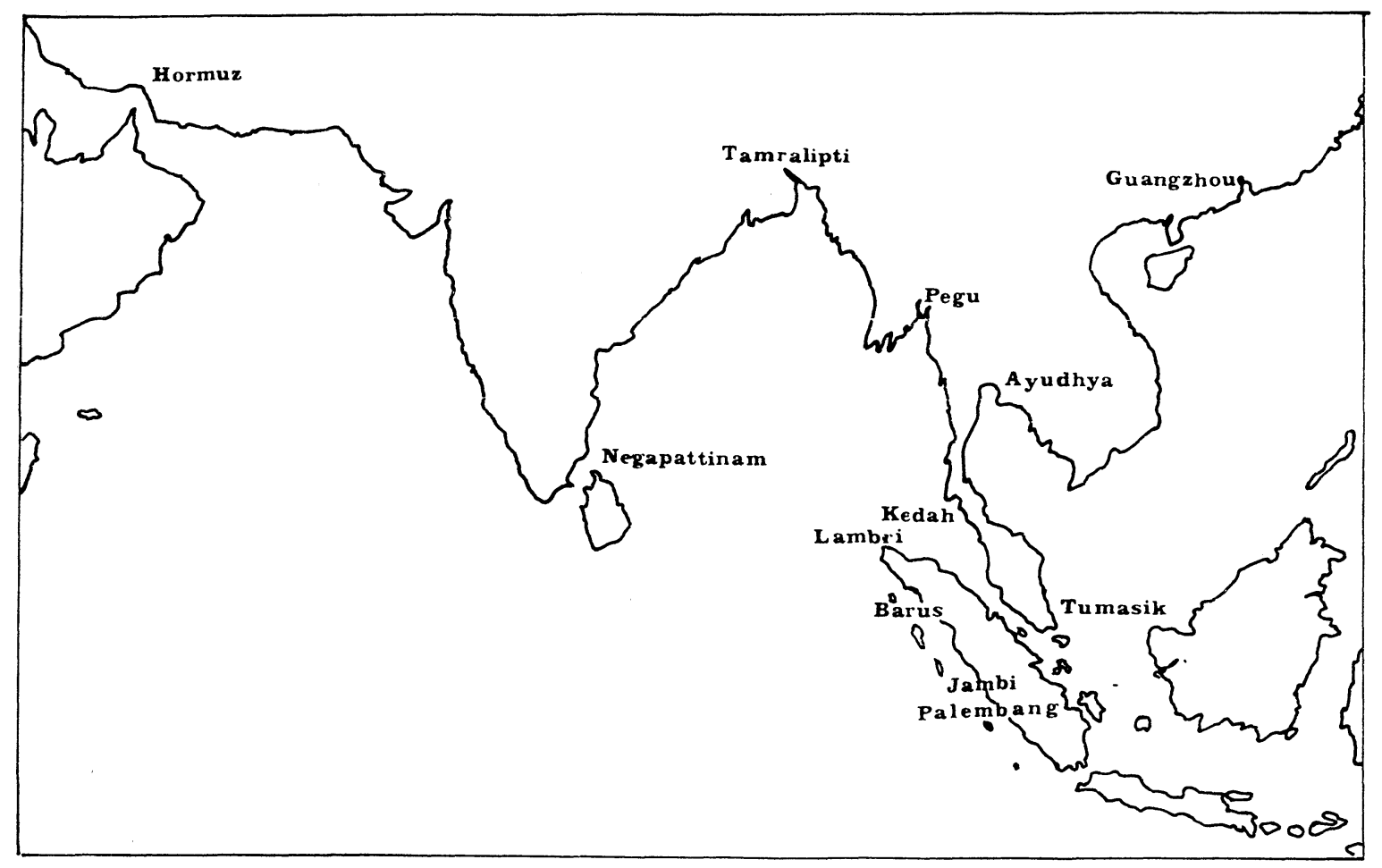

Fig. 1. The Indian Ocean and South China Sea.

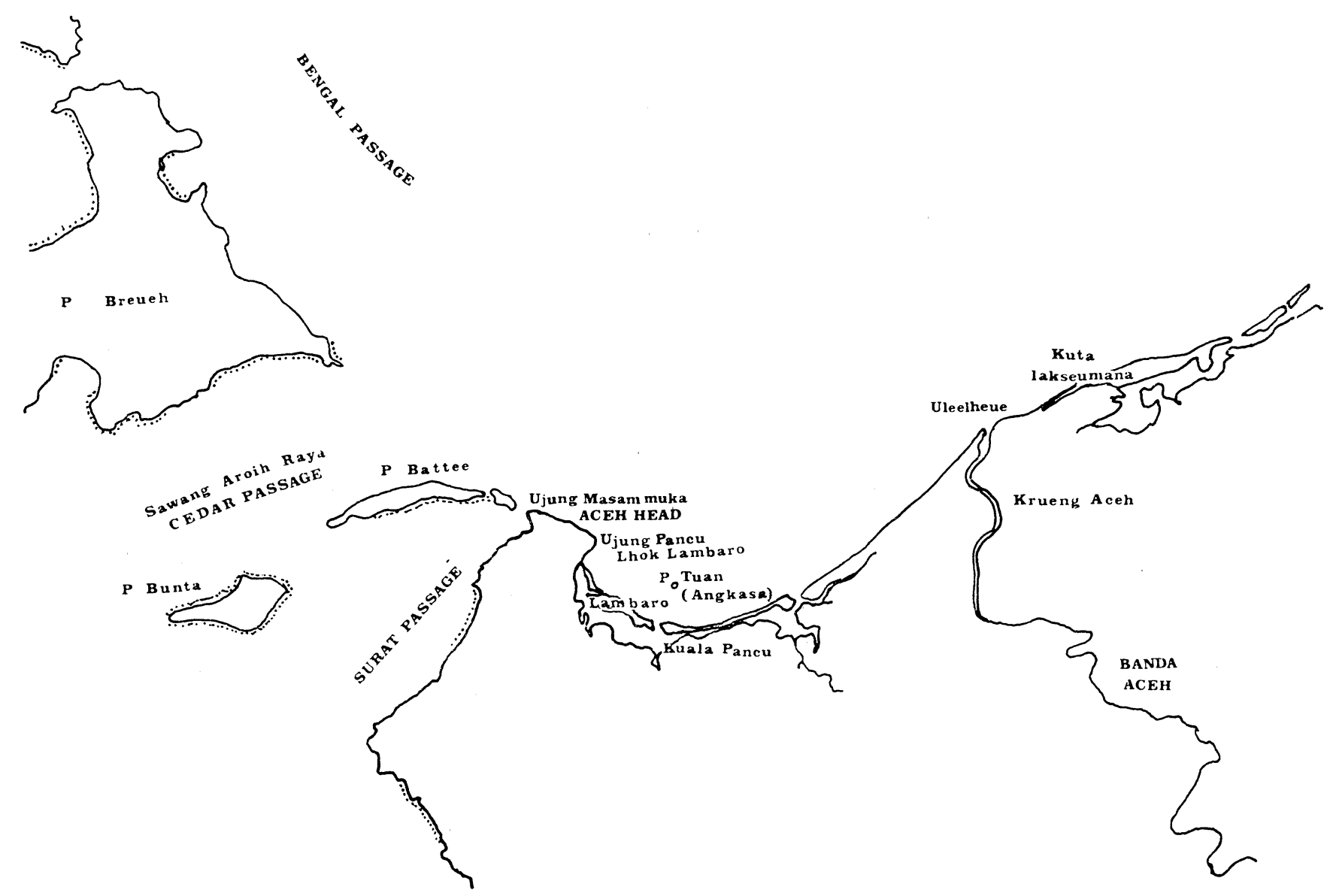

Fig. 2. Aceh: Lhok Lambaro and Aceh Head. 


\title{
BEYOND SERANDIB: A NOTE ON LAMBRI AT THE NORTHERN TIP OF ACEH
}

\author{
E. Edwards McKinnon
}

Historical geographers generally agree that the toponym known to the twelfth and thirteenth century Chinese as Lamuri, ${ }^{1}$ and to the Arabs in the late first millennium after Christ as Al-Ram(n)i, Ramri, or Ramli ${ }^{2}$ was situated in the region of Kuta Raja (now known as Banda Aceh) at the northwestern tip of Sumatra (Fig. 2). As recently as November 1984, it was stated, however, that the precise location of Lamuri, Lambri, or Ramni had not, as yet, been identified. ${ }^{3}$

The purpose of this article is to review the literature regarding the location and nature of Lambri, an important landfall and departure point for ships crossing the Indian Ocean in early times, and indeed much later, and to suggest why there seems to be such a paucity of archaeological evidence regarding the location of ancient Lambri. I will submit new evidence, albeit limited, to support the theory that the traditional location of Lambri is essentially correct ${ }^{4}$ and will also suggest lines for future research in the area.

\section{Historical References to the Northern Tip of Sumatra}

The timing of voyages across the Indian Ocean from South India and Sri Lanka to Southeast Asia was dictated by the monsoons. The voyage eastward would have been undertaken between April and September, sailing with the Southwest monsoon, and the voyage westwards between October and March, with the Northeast monsoon.

\footnotetext{
${ }^{1}$ I have, for convenience, referred to this area simply as Lambri. The Acehnese word lam means "in, inside" or "deep." It is also linked with the names of settlements. In the region of Aceh Besar, around the present-day Banda Aceh, place names with the prefix lam, are commonplace. See Hoesin Djajadiningrat, AtjehschNederlandsch Woordenboek, 2 vols. (Batavia: Landsdrukkerij, 1934), 1:872.

${ }^{2}$ For a full discussion of the various forms of the name as known to the Arabs and Chinese between the ninth and seventeenth centuries, see H. K. J. Cowan, "Lamuri-Lambri-Lawri-Ram(n)i-Lan-li-Lan-wu-liNan-po-li," Bijdragen tot de Taal-, Land-en Volkenkunde van Nederlandsch-Indië (hereafter BKI) 90 (1933): 421-24. For a full discussion of the Arab texts relating to Lambri (and Southeast Asia generally), see G. R. Tibbetts, A Study of the Arab Texts Containing Material on South-East Asia, Oriental Translation Fund, New Series Vol. XLIV (London: E. J. Brill published for the Royal Asiatic Society, 1979). See also Paul Pelliot, Notes on Marco Polo II (Paris: Imprimerie Nationale, Librarie Adrien-Masion Ncuve, 1963), pp. 761-62.

${ }^{3}$ Satyawati Suleiman, "Maritime Routes in the Classical Period" (Indonesian Country Report) in SPAFA Final Report: Consultative Workshop on Research on Maritime Shipping and Trade Networks in Southeast Asia (Bangkok: SPAFA, 1984), pp. 53-70. [SPAFA is the Southeast Asia Ministers of Education Project for Archaeology and Fine Arts. The Headquarters of SPAFA are situated in Bangkok.]

4 Whereas most authors appear to have associated Lambri with the northern tip of Sumatra, Valentijn, in his Beschryvinge van het eiland Sumatra, published in 1725, Werndly in his Maleische Spraakkunst (1735), and Marsden in The History of Sumatra, published in 1818, considered that the name referred to Jambi. See Teuku Iskandar, De Hikajat Atjeh, Verhandelingen van het Koninklijk Instituut voor Taal-, Land- en Volkenkunde, No. 26 (The Hague: Nijhoff, 1958), p. 27.
} 
During the period under consideration, between the ninth and seventeenth centuries, the first landfalls across the Bay of Bengal were Kedah on the Malay Peninsula 5 where Indianizing influences appear from the early first millennium after Christ, ${ }^{6}$ and the northwestern tip of Sumatra. By the end of the fourth century one toponym "P'o-lu" or "Barus," known from Chinese sources, is thought to relate to the northern part of Sumatra. ${ }^{7}$ It is not until the ninth century, however, that the Arab geographer Ibn Khurdadhbih mentions Ram(n)i: "Beyond Serandib is the isle of Ram(n)i, where the rhinoceros can be seen. ... This island produces bamboo and brazilwood, the roots of which are antidote for deadly poisons. ... This country produces tall camphor trees."8

About the same time, the Akhbar al-Sin wa'l Hind also refers to Ramni: "Ramni (which) produces numerous elephants as well as brazilwood and bamboos. The island is washed by two seas ... Harkand and that of Salahit."9 The name Ramni (or Ram[n]i) may, by virtue of its geographical position in respect of Serandib, be safely linked to northern Sumatra and, more particularly, the northwestern tip of Aceh. ${ }^{10}$ The presence of camphor also indicates a northwestern Sumatran location.

The name is also mentioned by Abu Zaid Hasan in 916, as he notes among the possessions of the Maharaja of Zabaj: "the island called Rami (Ramni) which is eight hundred parasangs ${ }^{11}$ in area. One finds brazil-wood, camphor and other plants." 12

In circa 943, Masudi states that:

At a distance of about a thousand parasangs (from Serandib) are still more islands called Ramin (i.e. Ramni) well populated and governed by kings. They are full of gold mines, and nearby is the land of Fansur, whence is derived the fansuri camphor, which is only found there in large quantities in the years that have many storms and earthquakes. ${ }^{13}$

The 'Aja'ib al-Hind, compiled circa 1000 A.C. has various references to Lambri. One Muhammad ibn Babishad is reported to have said that:

In the isle of Lamuri there are zarafa ${ }^{14}$ of an indescribable height. It was said that some shipwrecked sailors forced to go from the neighbourhood of Fansur to Lamuri, refrained from marching at night for fear of these zarafa; for they do not appear by day.... There are also in these islands extremely large ants, particularly in the island of Lamuri where they are enormous.

\footnotetext{
${ }^{5}$ In the earlier part of this period, Kakao island near Takauapa in southern Thailand attracted shipping in the seventh, eighth, and ninth centuries. See Alastair Lamb, "Kedah and Takuapa," Federation Museums Journal 6 (1961): 69-88.

6Ibid., p. 79, suggests that, although on Indian epigraphical grounds the Buddhagupta inscriptions of Kedah (written in an early form of Tamil Grantha script) may belong to the fourth century AD, they may actually be considerably later.

${ }^{7}$ For a full discussion of P'o-lu or Barus, see O. W. Wolters, Early Indonesian Commerce, A Study of the Origins of Srivijaya (lthaca: Cornell University Press, 1967), pp. 181-96.

8 Tibbetts, Arabic Texts, pp. 27-28.

9 Ibid., p. 25.

10 The sea of Harkand was the Bay of Bengal. Salaht (or Salahit) is believed to be derived from the Malay word selat or Straits, i.e., what is now known as the Selat Melaka. See Wolters, Early Indonesian Commerce, p. 178.

$11_{1}$ From the Persianfarsakh, it was approximately $3^{1 / 2}$ miles in extent. Tibbetts, Arabic Texts, p. 33.

12Ibid., p. 33.

13 Ibid., pp. 37-38.

${ }^{14}$ Van der Lith, Livre des Merveilles de l'Inde, identifies the zarafa as the two-horned Sumatran rhinoceros (Dicerorhinus sumatrensis). See Tibbetts, Arabic Texts, p. 140.
} 
He adds that he heard a sailor say that at "Lulubilank, which is a bay in the sea, 15 there were a people who ate human beings. These cannibals had tails, and lived between the land of Fansur and the land of Lamuri."16

Further references to Lambri in the works of other Arab geographers add little to what has been quoted above. The name Ramni is mentioned by Biruni in about 1030.17 It appears also in the Dimashqi text of $1325 .{ }^{18}$

The single Indian reference to Lambri appears in the Tanjore inscription of the Tamil sovereign Rajendra Cola, where the name "Ilamuridesam, whose fierce wrath rose in war" is mentioned along with other contemporary toponyms as targets of the Tamil raid of 1025.19

Writing in 1178, the Chinese geographer Chou Ch'u-fei refers to Lan-li where ships from Canton (Guangdong) waited for the monsoon to carry them across the Indian Ocean to Sri Lanka and India. ${ }^{20}$ Almost fifty years later, Chau Ju-kua refers to Lan-wu-li, reporting: "The products of the kingdom of Lan-wu-li are sapan-wood, ${ }^{21}$ elephants' tusks and white rattan. The people are warlike and often use poisoned arrows. With a north wind, one comes within twenty odd days to the kingdom of Silan. ..."22 He goes on to

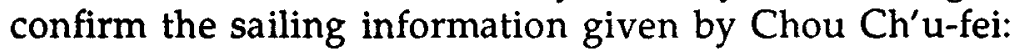

The Ta-shi are to the west and north (or north-west) of Ts'uan-chou at a very great distance from it, so that foreign ships find it difficult to make the voyage there direct. After these ships have left Ts'uan-chou they come in some forty days to Lan'li, where they trade. The following year they go to sea again, when with the aid of the regular wind they take some sixty days to make the journey. 23

In addition to the economic and geographical information regarding Lan-wu-li, Chau Jukua gives a glimpse of the political situation at the end of the twelfth century. He mentions Lan-wu-li in a list of "dependencies" of San-fo-ts'i (Srivijaya), ${ }^{24}$ which includes Kien-pi (possibly Pulau Kompei in Aru Bay), 25 Pat-ta (Batta or Batak) (possibly the Deli

${ }^{15}$ Tibbetts identifies this with Lho' Belang Raya (Telok Balang), $5^{\circ} 32^{\prime}$ N, $95^{\circ} 17^{\prime}$ E. Ibid., p. 141.

16 Ibid., pp. 44-45.

17 Ibid., p. 50.

18 Ibid., p. 62; Cowan, "Lamuri," p. 421.

${ }^{19}$ K. A. Nilakanta Sastri, History of Srivijaya (Madras: University of Madras, 1949), pp. 80, 81.

20 Almut Netolitzky, Das Ling-wai Tai-ta von Chou-chu-fei (Weisbaden: Heiner Verlag, 1977), pp. $40-41$.

21 Brazilwood (Caesalpinia sappan, Linn.). See below.

${ }^{22}$ Friedrich Hirth and W. W. Rockhill, Chau Ju-kua: His Work on the Chinese and Arab Trade in the Twelfth and Thirteenth Centuries, Entitled Chu-fan-chi (St. Petersburg: Imperial Academy of Sciences, 1911 ), p. 72.

${ }^{23}$ Ibid., p. 114. Hirth and Rockhill note that 'This (is) partly taken from Chou K' $\mathrm{u}$-fei .... ships leaving Ts'uanchou during or after the eleventh moon (December) and sailing with a northerly wind can make the country called Lan-li in forty days. Here they trade, buying sapan-wood, tin and long white rattans. The following year, in winter, they set to sea again and, with a north-easterly wind favouring them, they make the voyage to this country of Ma-li-pa (i.e. the Hadramaut coast of Arabia) in some sixty days." Ibid., pp. 119-20.

${ }^{24}$ Srivijaya at this time was presumably centered on Muara Jambi on the Batang Hari. See O. W. Wolters, "A Note on the Capital of Srivijaya during the Eleventh Century," in Essays Offered to G. H. Luce, ed. B. Shin, A. J. Boisselier, and A. B. Griswold, 2 vols. (Ascona: Artibus Asiae, 1966), 1:225-39.

${ }^{25}$ See E. Edwards McKinnon and Tengku Luckman Sinar, "A Note on Pulau Kumpeh in Aru Bay, Northeastern Sumatra," Indonesia 32 (1981): 49-73. Chau's references to Kompei or Kumpeh do, however, mention tin which comes cither from the Malay peninsula or from islands offshore southeastern Sumatra. The references may include information relating to Muara Kumpeh on the Batang Hari in Jambi. See also E. Edwards McKinnon, "A Brief Note on Muara Kumpeh Hilir: An Early Port Site on the Batang Hari," SPAFA Digest 3,2 (1982): 37-40, and "New Data for Studying the Early Coastline in the Jambi Area," Journal of the Malaysian Branch of the Royal Asiatic Society (hereafter JMBRAS) 57, 1 (1984): 56-65. 
area of northeastern Sumatra ${ }^{26}$ but conceivably the Pardembanan Batak area of Asahan and adjoining Simelungun, also in northeastern Sumatra) ${ }^{27}$ and Pa-lin-fong (Palembang) in southeastern Sumatra. Sin-f'o (Sunda) is also mentioned, as are several toponyms in the Thai isthmus/Malay peninsula area and Si-lan (Sri Lanka). ${ }^{28}$ What the term "dependency" actually meant is difficult to ascertain. It probably implied the sending of annual tribute rather than any direct political subjugation.

After the Tamil raid of the early eleventh century, the former stability of the Malay polities in the area of the Selat Melaka was upset and the area apparently became increasingly unsettled. By the fourteenth century anarchy prevailed.29

Marco Polo, returning from China to Europe in 1292, mentions, in addition to Perlak which had gone over to Islam, the name Lambri along with five other "heathen" kingdoms in northern Sumatra. He notes that: "The people are Idolaters, and call themselves subjects of the Great Kaan. They have plenty of Camphor and all sorts of other spices. They also have brazil in great quantities. ..."30 In both 1284 and again in 1286, Lambri is recorded as having sent tribute to the recently established Yuan dynasty in China. ${ }^{31}$

The Persian traveler Rashiduddin in 1310 noticed that merchants from many countries came to Lamori, 32 and in 1323, Friar Odoric of Pordenone found it to be a center of trade where there were merchants from distant lands and camphor, gold, and lign-aloes were available. Here he began to lose sight of the North Star. ${ }^{33}$

\footnotetext{
${ }^{26}$ See A. C. Milner, E. Edwards McKinnon, and Tengku Luckman Sinar, "A Note on Aru and Kota Cina," Indonesia 26 (1978): 1-42.

${ }^{27}$ See E. Edwards McKinnon, "Kota Cina: Its Context and Meaning in the Trade of Southeast Asia in the Twelfth to Fourteenth Centuries" (PhD dissertation, Cornell University, 1984), pp. 329-30, n. 47.

28 Hirth and Rockhill, Chau-Ju-kua, p. 62.

${ }^{29}$ Wang Ta-yuan, for example, in his description of Lung Ya Men or Tumasik (Singapore), refers to the situation at the eastern end of the Selat Melaka in the mid-fourteenth century, stating that "the people are accustomed to pillage." He goes on to say that "As there is neither good timber in the mountain nor fine goods for tribute, (the natives of Tumasik) could only trade with Chuan-chou with booty and plunder. When vessels sail to the west sea, the natives are quite at ease, but on their return voyage the crew have to put up arrow shelters and curtains, and sharpen their weapons against pirates, especially when they arrive at Chi-Li-Men (Karimun Islands). Two or three hundred boats of the pirates would come on silently and fight for several days. It would be fortunate if the traveller could meet a fair wind; otherwise the crew would be butchered and the merchandise would be looted." Wang also refers to Chinese settlers living in Tumasik at this time. Hsu Yun-Ts'iao, "Singapore in the Remote Past," JMBRAS 45, 1 (1972): 1-9.

${ }^{30}$ See Henry Yule and Henri Cordier, The Book of Ser Marco Polo, 2 vols. (Reprint, Amsterdam: Philo Press, 1975), 2:299.

31 Pelliot, Notes, p. 761.

32 Ibid.

${ }^{33}$ Yule and Cordier, Ser Marco Polo, p. 300, n. 1. Odoric mentions that the people of Sumoltra (Samudra-Pasai) were in constant war with those of Lamori. "The inhabitants (of Lamori) were very dark skinned, wrapped their bodies with silk stuffs, went bareheaded and barefoot. They used their hands in taking food. They were warlike and often used poisonous arrows. .. Household vessels are of bronze. The king is black, with unkempt hair and wears no covering on his head; he wears no regular clothes, but is merely wrapped in cloth of various colours, and his feet are protected by sandals of red leather (fastened) with gold thread. When going out he rides on an elephant or in a kind of litter. He cats every day a paste made of betel-nuts, burnt together with real pearl ashes. His palace is decked with jewels. There is an castern and western palace [read 'throne hall'], at each of which is planted a golden tree. ... Underncath each of these trees there is a golden throne with partition walls of glass. When holding court the king ascends the eastern throne in the morning and the western throne in the evening [an Indu custom]. Two attendants constantly hold up a golden dish [read 'spittoon'] to receive the dregs of the betel-nuts chewed by the king. ..." Whether or not this is all intended to apply to Lambri is unclear. Gerini notes, however, that both Marco Polo and Odoric recount the same tale
} 
Wang Ta-yuan, writing in 1349, refers to Nan-wu-li, of which he says:

This place is the most important trade centre in Nan-wu-li. Great mountain-like waves dash against it, it is on the edge of the Jih-yueh wang Sea in which it is doubtful there is any land.

The natives live all over the hills, each family in its own house. Both men and women do up their hair in a knot and leave the upper part of their bodies bare, wrapping a piece of cloth around them as a sarong. The soil is poor, the crops sparse, the climate hot. As to their customs, they are given to piracy like the people of Niutan-hsi (Tumasek).

The native products are cranes' nests, shells of turtles, tortoise-shell and lakawood, superior to any other in aroma.

The goods used (by the Chinese) in trading here are gold, silver, iron-ware, rosewater, red ssu pu (muslin), camphor, ${ }^{34}$ porcelain ware with designs in blue and white, and such things.

A ship on its homeward voyage may escape the winds and waves and good luck may have carried it clear of all dangers from monsters of the deep, but when passing this place it will without doubt fall into the tiger's mouth unless it can quickly catch "the violet [or 'violent'] wind" 35 and make off. ${ }^{36}$

The reference might well be to the strong currents and rocky shores of the islands immediately west of Ujung Masam Muka (Aceh Head). ${ }^{37}$ Strong tidal streams run in the Aroih Raya (Cedar Passage) between Pulau Peunasu and Pulau Batee and in the Aroih Cut (Surat Passage) between Pulau Batee and the coast between Ujung Masam Muka and Ujung Raja. ${ }^{38}$ Tide-rips, appearing like breakers, form in Aroih Raya and Aroih Cut; they

about a gem belonging to the kings of Lambri, Ceylon, and Nicobar. See G. E. Gerini, Researches on Ptolemy's Geography of Eastern Asia (London: Royal Geographic Society, 1909), pp. 679-80, n. 1.

${ }^{34}$ The reference to camphor (kapur baros) by Wang Ta-yuan as an item of trade used by the Chinese is interesting. Baros (or Fansur: see below), some distance south of Lambri on the west coast of Aceh, was renowned for the quality of its camphor. A South Indian trading community had established itself at Lobu Tua (the name means "deserted village" in Toba Batak), near Barus and set up a stele inscribed in Tamil Grantha characters in AD 1088. Wang's remark seems to imply that Chinese traders sold camphor to the inhabitants of Lambri, presumably not only for immediate use but also, presumably, for resale.

35 The term "violet wind" may be a misprint in Rockhill's rendition of Wang's description of Lambri. Professor Wolters advises me that another version of Wang Ta-yuan's text substitutes the character 79 ("also") for 考, which is the character in Rockhill's version. The character 考 means "red" and is used in rendering "Red Earth Land." It is used also in a poem written by Wang Ch'ang ling (?698-757) which reads "A red wind destroys China. A fierce fire leaves no nests behind." Wang Ta-yuan may have been embellishing his own text with a classical allusion. Professor Wolters suggests that "red wind" may, therefore, mean a "powerful wind." This, in turn, could suggest that an crror appears in T'oung Pao and that Rockhill actually intended to write "violent." Evidently the wind in question was a strong one.

${ }^{36} \mathrm{~W}$. W. Rockhill, "Notes on the Relations and Trade of China with the Eastern Archipelago and the Coast of India during the Fourteenth Century, 2," T'oung Pao 16 (1915): 61-159. See also Pelliot, Notes, p. 761; Cowan, "Lamuri,' p. 421.

37Yule quotes the Turkish author of the Molut, who says, "If you wish to reach Malacca, guard against seeing JAMISFULAH (possibly Pulau Beras), because the mountains of Lamri advance into the sea, and the flood tide there is very strong." This, he says, evidently means "Don't go near enough to Aceh Head to see even the islands in front of it." De Barros mentions that Gaspar d'Acosta was lost on the island of Gomispola. See Yule and Cordier, Ser Marco Polo, p. 307.

38 See Malacca Strait and West Coast of Sumatra Pilot, 5th ed. (London: Ministry of Defence, Hydrographic Department, 1971), p. 42. The east-going stream has a rate of from 4 to 5 knots at springs and the west-going stream from 5 to 6 knots; they run strongest along the northern side of Pulau Batee. During the west-going 
are most violent with the wind against the stream, but are comparatively moderate in the north-east monsoon. There is an eddy off Lumpat, which, combined with the tidal stream setting between Pulau Bunta and Pulau Batee, causes a confused sea, which sometimes assumes the character of a whirlpool. It may be seen that the seas hereabouts could be extremely dangerous for sailing vessels at certain times of the year. ${ }^{39}$

Then in 1365, the Javanese chronicle Nagarakrtagama describes Lamuri as a dependency of Majapahit. ${ }^{40}$

Writing in the early fifteenth century, Ma Huan refers to Nan-po-li, visited by the Ming fleet under the eunuch admiral Cheng Ho:

This country lies beside the sea, (and) the population comprises only something over a thousand families. All are Muslims, (and) they are very honest and genuine. On the east the territory adjoins the boundary of the king of Li-tai, on both west and north, it abuts on the great sea; if you go south, there are mountains; and south of the mountains there is the great sea again. 41

Ma Huan also mentions Pulau Wei $\left(5^{\circ} 54 \mathrm{~N}, 9^{\circ} 13^{\prime} \mathrm{E}\right)$, an island some nine nautical miles $(16.6 \mathrm{~km})$ offshore to the northwest of Aceh where there is a fine natural harbor, now the modern port of Sabang. Pulau Wei is often mentioned in historical sources and in translation from Chinese as "Hat island." Mills, however, concludes that the full Chinese name was $C h^{\prime} i e h-n a n-m a o$, a rendering of kelembak, the finest kind of lign-aloes. He notes that, to represent the sound mao, the Shun-feng uses the character meaning "face," and hence Gerini and Pelliot were both wrong in thinking that mao should be translated as "hat." 42

Ma Huan describes Pulau Wei as:

Lying in the sea to the northwest of that country (Lambri) where there is a large flattopped steep mountain, which can be reached in half a day; its name is Mao mountain. On the west of this mountain, too, it is all the great sea; indeed, this is the western Ocean (this area being) named the Nan-mo-li ocean, ships coming across the ocean from the west take in sail (here), and they all look to this mountain as a guiding mark.

In the shallow water, about two chang deep, 43 at the side of the mountain there grows a marine tree; the people there recover it, and sell it as a valuable commodity; this is coral.

This country is subject to the jurisdiction of the country of Nan-po-li. 44

stream there is an eddy setting southward from Ujung Empec, and there is a strong inset between Pulau Batee and Pulau Usamlakoh.

${ }^{39}$ There appear to be some differences regarding the use of names of the various islands off Aceh Head. The name Pulau Beras, (or Bruas) mentioned by Yule does not appear in the Malacca Strait Pilot. The modern name is Pulau Breueh.

${ }^{40}$ Th. C. Th. Pigeaud, Java in the Fourteenth Century, 5 vols. (The Hague: Nyhoff, 1960), 1:11.

41 Mills, Ma Huan, pp. 122-23. It is interesting to note that this is the first literary reference to appear regarding the establishment of Islam in Aceh. DasGupta places the Islamicization of Aceh "somewhere between 1349 and 1412." For a full discussion of this matter, see Arun Kumar DasGupta, "Aceh in Indonesian Trade and Politics: 1600-1641" (PhD dissertation, Cornell University, 1962), pp. 10-16.

42 Mills, Ma Huan, p. 123.

43 Mills notes that this was the equivalent of 20 fect 4 inches $(6.01 \mathrm{~m})$. Ibid., p. 123, n. 7 .

${ }^{44}$ lbid., pp. 123-24. 


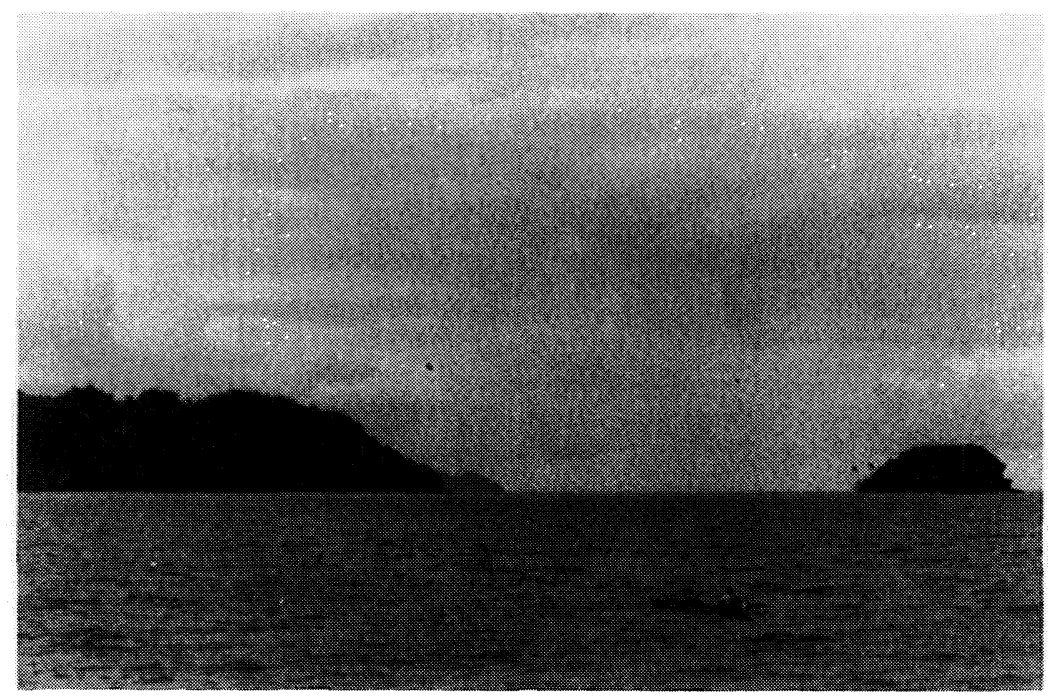

\section{Lhok Lambaro}

Plate 1. Ujung Pancu and Pulau Tuan, with Ujung Masam Muka (Aceh Head) in the background.

Plate 2. Pulau Tuan (Pulau Angkasa) from Kuala Pancu, with Pulau Wei in the background. There is a relatively deep passage between Pulau Tuan and the shore.
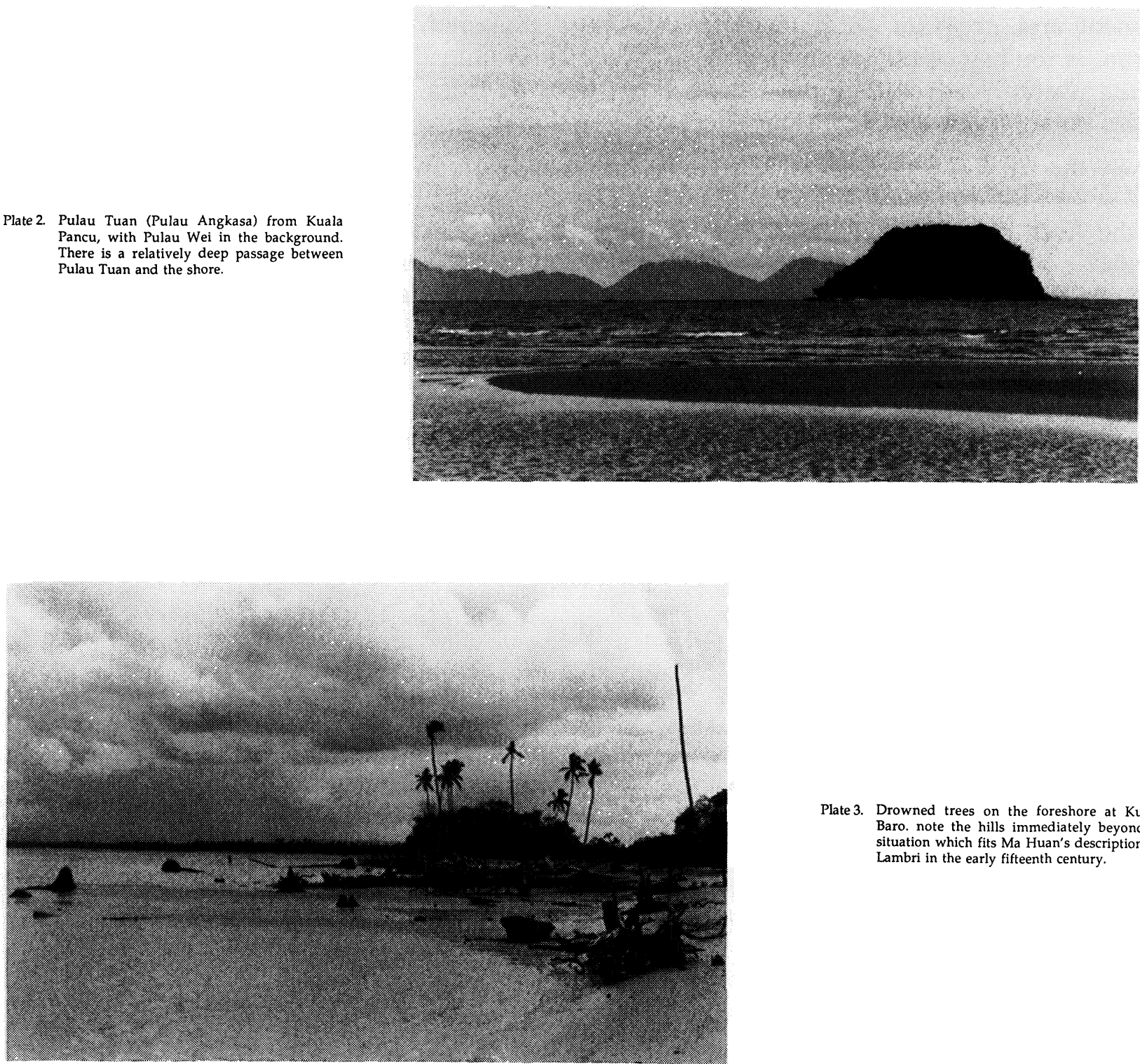

Plate 3. Drowned trees on the foreshore at Kual Baro. note the hills immediately beyond, situation which fits Ma Huan's description of Lambri in the early fifteenth century. 
Finally, in the early sixteenth century, Tome Pires gives a most precise description of the location of Lambri. He states that: "Achin is the first country on the channel side of the island of Sumatra, and Lambry is right next to it, and stretches inland, and the land of Biar 45 is between Achin and Pedir, and now these countries are subject to the king of Achin and he rules over them and he is the only king there. This king is a Moor. ..."46

Although the toponym Lambri and the various other versions of the name initially referred to the whole northern coastal area of Aceh, it seems that later references indicate one specific point which would have provided both a safe anchorage for shipping, protected from the swells of the Bay of Bengal, a source of supplies, albeit at times perhaps rather meager, and a source of fresh water. The Hikayat Atjeh provides one further clue. There is, on page 17 of the manuscript published by Teuku Iskandar, a reference to teluk Lambri, the "bay of Lambri." 47 There are but two bays of any consequence which would appear to be suitable as a safe anchorage for shipping on this northwest coast of Aceh, namely Lhok Lambaro and Krueng Raya. Of these, the one location which appears to meet best the above criteria and which fits the descriptions of both Ma Huan and Tome Pires in that it lies adjacent to modern Banda Aceh, the site of the former sultans' settlement and provides an immediate anchorage sheltered, in some degree, from the ocean, is the bay of Lhok Lambaro $\left(5^{\circ} 40^{\prime} \mathrm{N}, 95^{\circ} 03^{\prime} \mathrm{E}\right)$ immediately east of Ujung Masam Muka (Aceh Head) and Ujung Pancu. From here, as from other parts of the northern coast, Pulau Wei is clearly visible. ${ }^{48}$

By the (late) fifteenth century, it seems that there were two centers of power in Aceh, one at Lambri on the coast and a second at Dar al-Kamal situated on the southern bank of the Aceh river. ${ }^{49}$ The Hikayat Atjeh, mentioned above, gives the genealogy of Sultan Iskandar Muda (1607-1636) on both his father's and mother's sides, and indicates that his father's people ruled at one time in Lambri whilst his mother's family ruled in Dar alKamal. ${ }^{50}$ By the early sixteenth century, a single center of power was firmly established in the area which, in the eighteenth century, became known as Kuta Raja (King's fort), a short distance inland up the Krueng Aceh or Aceh river. 51

There may have been both political and geological reasons as to why the seat of power no longer centered on Lambri. Pires refers to Aceh as a small pirate state which had formerly been subject to Pidie. ${ }^{52}$ Because of the insecurity which existed on this coast in the late fifteenth and early sixteenth centuries it may have been necessary to move

\footnotetext{
${ }^{45}$ Biar is Biheue ( $\left.5^{\circ} 32^{\prime} \mathrm{N}, 95^{\circ} 47^{\prime} \mathrm{E}\right)$, situated between Ujung Mataie and Ujung Pidie.

46 Armando Cortesao, The Suma Oriental of Tome Pires (London: Hakluyt Society, 1944), pp. 137-38.

47 Iskandar, De Hikajat Atjeh, p. 73.

48 I do not rule out entirely the other possible alternatives, of which there are perhaps two, one near the mouth of the Krueng Angan west of Kuala Aceh which secms too exposed and the second, favored by Teuku Iskandar, at Teluk Krueng Raya. Of the latter, the Malacca Strait Pilot remarks that "the bay is inconveniently deep for anchorage, and the western side of the bottom is foul, but it is the only anchorage on the northern coast that is usually free from swell in both monsoons." It precedes this with the remark "Krueng Raja baai.Danger," Malacca Strait Pilot, p. 56. This alternative has its obvious drawbacks. But see Teuku Iskandar's discussion of the possible site of Lambri: Iskandar, De Hikajat Atjeh, pp. 24-29. He notes that in the eighteenth century Krueng Raya was an important trading center. My cursory investigation of the Krueng Raya area in 1977 failed to yield any tangible evidence of early habitation but further, more intensive, investigations may well yield results.

${ }^{49}$ DasGupta, Aceh, p. 26.

50 Ibid., and Iskandar, Hikajat Atjeh, pp. 37-38.

${ }^{51}$ DasGupta, Aceh, p. 27.

52 Cortesao, Suma Oriental, p. 139.
} 
inland for, as Pires indicates, Pidie was continually at war with Aceh ${ }^{53}$ and an inland settlement would have been less exposed to attack than a coastal one. It is possible also, however, that the ancient port site of Lambri was, as we shall see, an area already geologically unstable and sinking beneath the waters of the bay by the sixteenth century, hence the establishment of Lambaro, the "new settlement."

\section{Items of Trade}

There are several items of trade mentioned in the above references which were either produced in Lambri or available there. I do not intend to discuss these in great detail. It will, however, be useful to review briefly the types of commodities which were available.

Brazilwood. Brazilwood or Sappanwood is the dark-red heartwood of Caesalpinia sappan, Linn. which was used by the Chinese as a dye for coloring food and by Hindus as face marks in the Holi festival. It was also used for dyeing matting and for tanning. It may also have certain medicinal properties. ${ }^{54}$ This was, almost certainly, a primary product from the hinterland of Lambri.

Camphor. Camphor or Kapur Baros is an aromatic resin obtained from the camphor tree, Dryobalanops aromatics, Gaert. Camphor of extremely good quality was obtained from the area of Baros or Fansur, ${ }^{55}$ some distance south of Lambri on the northwest coast of Sumatra. The best quality of all came actually from the valley of the Lau Cinendang, where a unique combination of soil and climate allowed it to flourish. ${ }^{56}$

Barus was already renowned for the quality of its camphor by the early to mid first millennium AD. By the late eleventh century, a community of South Indian merchants had established themselves at Lobu Tua, near Barus where two (possibly three) inscriptions, a Buddha image, and numerous other archaeological artifacts, including Chinese ceramics and a fragment of an Islamic glazed bowl, have been discovered indicating that there was, in all likelihood, a permanently settled foreign community there. ${ }^{57}$

\footnotetext{
53 Ibid.

${ }^{54}$ See Isaac H. Burkill, A Dictionary of Economic Products of the Malay Peninsula, 2 vols. (Kuala Lumpur: Ministry of Agriculture and Cooperatives, 1966), 1:389-97. See also Paul Wheatley, "Geographical Notes on Some Commodities Involved in Sung Maritime Trade," JMBRAS 32, 2 (1959): 108-9.

55 "Fansur" or "Pancur," derived from a Malay word pancur, meaning spring or source of water, is generally accepted as relating to the region of Barus. For a discussion of the various forms of the name, which first appears in Arab texts in the middle of the ninth century, sce Pelliot, Notes, pp. 661-70. In discussing coastal-hinterland relationships between the seventeenth and twentieth centuries, Jane Drakard reminds us that there is still a small village known as Panchur (Pancur) in the Barus region. See Jane E. Drakard, "A Malay Frontier: The Adaptation of Malay Political Culture in Barus" (MA thesis, Monash University, 1984), p. 17. But see also L. Van Vuuren, "De handel van Baroes, als oudste haven op Sumatra's Westkust verklaard en voor de toekomst beschouwd,"Tijdschrift voor Indische Taal-, Land- en Volkenkunde (hereafter TBG) 25, 2 (1908): 1389-1402, especially the map on p. 1392.

56 For a full discussion on the botanical and economic aspects of camphor, see Burkill, Economic Products 1:876-82. For discussions of the historical aspects of the camphor trade, see Wolters, Early Indonesian Commerce, pp. 121-27, etc.

57 The earliest recorded archacological observations in the Barus area were made in 1885. See G. J. J. Deutz, "Baros," TBG 22 (1885): 156-63. For a recent review of discoveries in the Barus area, see J. N. Miksic, "Classical Archacology in Sumatra," Indonesia 30 (1980): 43-66, especially pp. 59-62.
} 
Although Chau Ju-kua does not mention camphor being traded in Lambri, one wonders if the names Ujung Pancu and Kuala Pancu ${ }^{58}$ in Lhok Lambaro a short distance west of Banda Aceh could, perhaps, also relate to the name "Fansur." Ships would have had to round Ujung Pancu en route from Lambri to Barus and the name would have been, in all likelihood, known to mariners in earlier times. Could the name, perhaps, have given rise to some toponymic confusion between this part of Aceh and the Barus region? Or, by virtue of having been applied to the whole of the northwest coast, indicate an entrepot trade in camphor in Aceh in earlier times?

Writing in the early eighth century, Chia Tan, author of the Hsin T'ang shu, mentions, albeit somewhat ambiguously, the port of $\mathrm{P}^{\prime} \mathrm{o}-\mathrm{lu}$, rich in gold, mercury, and camphor. It was the point of departure for ships bound from western Srivijaya across the Indian Ocean to Sri Lanka. Should, as Professor Wolters suggests, P'o-lu equate with Ramni (Lambri), 59 the name Pancu would be a fitting candidate for this.

Coral. This came from Pulau Wei. Certain red varieties of coral were highly valued in earlier times. ${ }^{60}$

Cranes' Nests. I have been unable to discover any information regarding this particular commodity reported by Wang Ta-yuan. Certain birds' nests are, however, thought to have magical properties. ${ }^{61}$ Skeat, in discussing aspects of Malay magic, mentions the ruwak ruwak "a kind of Heron whose nest, if discovered would give the possessor the power of becoming invisible (alunun)." 62 It is not clear whether the cranes' nests available at Lambri were purchased for the Chinese market or for resale elsewhere in the Malay world.

Gold. Any gold available in Lambri would have presumably come from the hinterland of Lambri in the Bukit Barisan mountains where gold-bearing deposits are known from a number of locations. The most important are in the Meulaboh area, but other sources are known on the west coast near Lhok Kroeet, and near Calang. ${ }^{63}$ Pires notes that in the early sixteenth century, gold was carried over the mountains from Meulaboh to Pedir ${ }^{64}$ and gold dust was traded in Pasai. ${ }^{65}$ It seems likely that some gold was available in Lambri even from the earliest times, for gold was apparently carried over long distances in Sumatra. Later, after Aceh secured access to the coast of the Minangkabau area in the sixteenth century, it became an important center for the gold trade. ${ }^{66}$

Ivory. Ivory from the Sumatran (= Indian) elephant (Elephas maximus) would have been readily available. Marsden notes that "the forests (of Sumatra) abounding in elephants, ivory (gading) is consequently found in abundance." He goes on to note that "the animals themselves were formerly the objects of a considerable traffic from Achin to the coast of Coromandel, or kling country, and vessels were built expressly for their trans-

\footnotetext{
58 The name pancu in Malay is that given to a kind of tree bearing a large, green sweetish fruit. R. J. Wilkinson, A Malay-English Dictionary (Romanised) (London: Macmillan, 1959), p. 839.

59 Wolters, Early Indonesian Commerce, p. 191.

${ }^{60}$ See Wheatley, "Geographical Notes," pp. 77-80.

${ }^{61}$ See Burkill, Economic Products 1:332.

62 See Walter W. Skeat, Malay Magic (Reprint. Singapore: Oxford University Press, 1984), p. 124.

${ }^{63}$ See P. J. Jansen, B. B. Lindberg, and H. Wolvekamp, "Ertsonderzoekingen in Atjeh en Onderhoorigheden," Jaarboek van het Mijnwezen in Nederlandsch Oost-Indie 2, 1 (1919): 130-62.

${ }^{64}$ Cortesao, Suma Oriental, p. 140.

65Ibid., p. 144.

${ }^{66}$ Christine Dobbin, Islamic Revivalism in a Changing Peasant Economy: Central Sumatra, 1784-1847, Scandinavian Institute of Asian Studies No. 47 (London: Curzon Press, 1983), p. 64.
} 
port. ..."67 Numbers of elephants have been sadly depleted since the early nineteenth century, but they are still to be found in the jungles of Aceh.

Lign-aloes. This is the kalambak or kelembak of the Malay, a pathologically diseased fragrant wood (Aquilaria Lam.), valuable for use as an incense and presumably available as a primary product in Lambri. 68

Rattan. Rattans are the stems of climbing plants of some seven genera of the subfamily Lepidocaryeae, family Palmae, which have numerous commercial uses in the modern world, mainly for furniture and basketry. Certain varieties are durable enough to serve as anchor cables and mooring ropes, others are used for matting and house construction. 69

Tin. This is mentioned by Chau Ju-kua as being purchased by Arabs on their return to the west. No tin exists naturally in this part of Sumatra, which suggests that it was brought from Kedah or elsewhere on the Thai/Malay peninsula especially for the convenience of traders who were not calling at peninsular harbors. It was, in fact, a reexport from Lambri to Murbat in Hadhramaut. ${ }^{70}$ Chau Ju-kua also mentions tin as an export from Kompei in northeastern Sumatra at this time. This would also appear to be part of the same network of "local" trade, in which commodities from elsewhere were fed into harbors on the main shipping routes.

Tortoise or Turtle Shell. Tortoise shell was believed to be able to detect poison. ${ }^{71}$ The best quality tortoise shell comes from the marine Hawksbill turtle (Eretmochelys imbricata, Linn.) which is widespread throughout the tropics but relatively scarce numerically. For about two millennia tortoise shell has been imported into China where it is used extensively for decorative purposes. ${ }^{72}$

\section{Archaeological Evidence}

It seems somewhat surprising that Lambri should disappear seemingly without a trace, for the toponym related to a fairly limited stretch of coast and references to it cover a period of some seven hundred years. Uninformed, early twentieth century Dutch writing on pre-Islamic antiquities in Aceh Besar has tended to distract attention from the likely nature of earlier archaeological remains in this area. ${ }^{73}$ In fact, the only recognizably pre-Islamic Buddhistic image from Aceh to have come to the attention of archaeologists

${ }^{67}$ See William Marsden, The History of Sumatra (1811: Reprint ed. Kuala Lumpur: Oxford University Press, 1966), p. 176.

${ }^{68}$ See Burkill, Economic Products 1:198-206.

69 See ibid., 2:1902-10; and Wheatley, "Geographical Notes," pp. 107-8.

70 see Wheatley, "Geographical Notes," pp. 115-17.

${ }^{71}$ See Hirth and Rockhill, Chau Ju-kua, p. 223n.

72 See Burkill, Economic Products 1:950-51; and Wheatley, "Geographical Notes." pp. 81-82.

${ }^{73}$ See, for instance, W. Goldie, "Het een en ander over Oudheidkundige Monumenten in de XXVI Moekims (IX Moekims Toengkoel) in Groot Atjeh," TBG 53 (1911): 301-13. Henri Chambert-Loir notes that Professor Lombard could see no trace of pre-Islamic influence in the "fort" at Indrapatra. See Henri Chambert-Loir, "Rapport de Mission a Aceh," Bulletin de l'Ecole Francaise d'Extreme Orient (hereafter BEFEO) 64 (1977): 303-10. I agree entirely. This and similar structures at Krueng Raya are of relatively modern construction and probably date to no earlier than the mid- to late-sixteenth or early seventeenth centuries. 
and art historians is the exquisite Lokesvara head recovered from an unidentified location as long ago as 1880 . It is now in the Musium Nasional, Jakarta. ${ }^{74}$

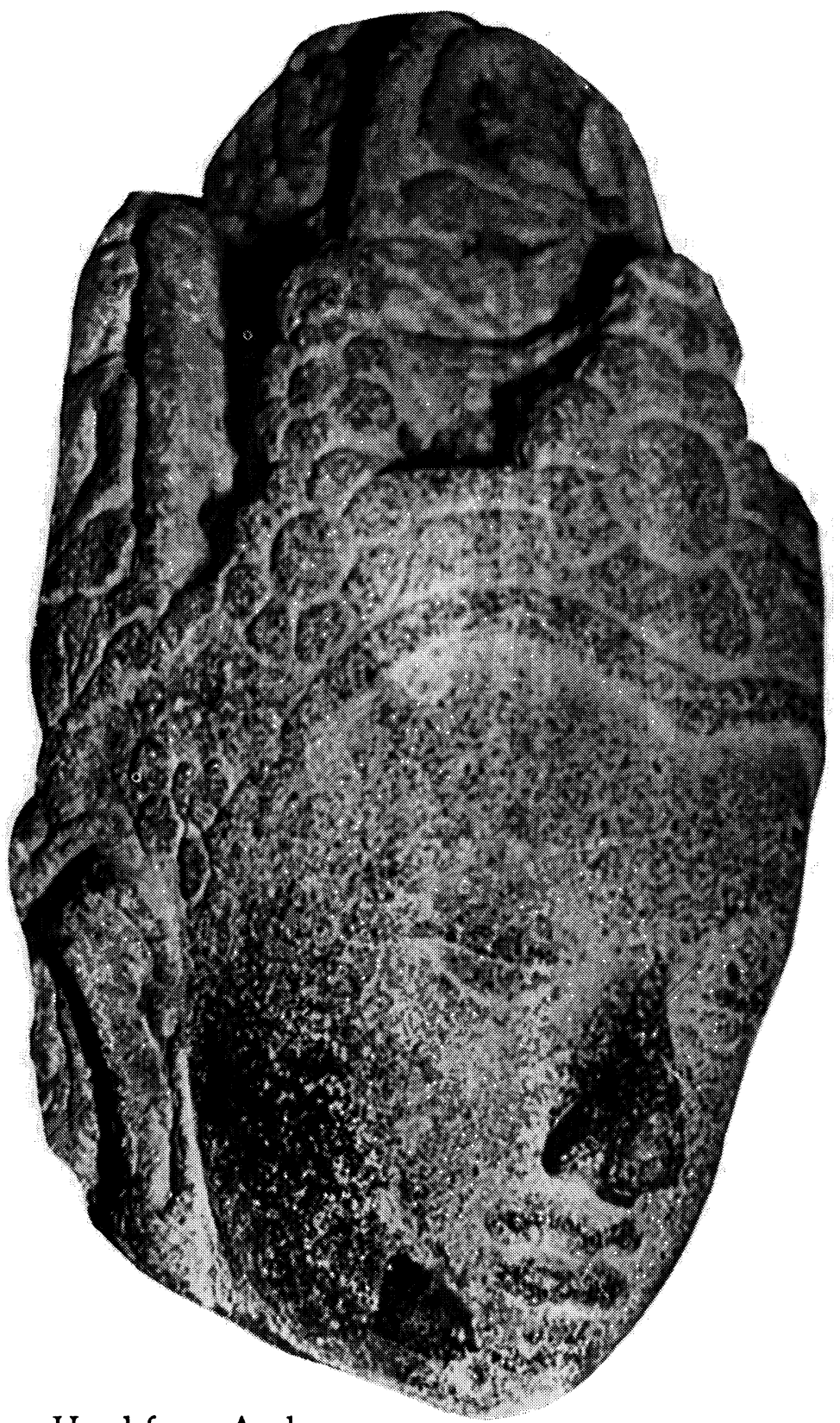

Plate 4. Lokesvara Head from Aceh:

Recovered from an unrecorded location in 1880, this exquisite sculpture may have come from Lambaro. The makota or crown is stylistically very similar to that of a small bronze Cunda from Polonarruva in Sri Lanka, dated to the tenth century and now in the British Museum.

\footnotetext{
${ }^{74}$ Notulen van het Bataviaasch Genootschap (1880), pp. 47-48. For a discussion on the dating and stylistic affinities of this head, see Eva Krebs, "Ein Bodhisattva aus Atjeh (Sumatra)," Ostasiatische Zeitschrift [Berlin] 18 (1942-43): 58-61. It would appear, however, that it is stylistically closer to a small bronze Cunda from Polonarruva in Sri Lanka which dates perhaps from the ninth century than to the sculptures of Central Java. Considering the close trading relationships between South India, Sri Lanka, and Aceh, it seems more likely that the sculpture relates to South Indian or Sri Lankan imagery than to that of Central Java. Images of South Indian origin have been found, after all, elsewhere in northern Sumatra, i.e., at Kota Cina.
} 
Perhaps, significantly, no other Hindu Buddhistic remains have been recovered in Aceh since then, despite the fact that tradition ascribes a "Hindu" period to Acehnese history. ${ }^{75}$ Even so, it does seem logical and indeed likely that there was a pre-Islamic, Hindu, or Hindu Buddhist, phase in Acehnese history. L. F. Brakel has argued persuasively for the survival of pre-Islamic influences in Acehnese concepts of kingship during the seventeenth century and points out that the continuity of Hindu concepts in the Acehnese state is symbolized by the perpetual devotion and respect shown to former seats of royal power such as Pasai and Makota Alam. ${ }^{76}$ He states that "the sultanate of Aceh can best be understood within the general context of the 'Hinduised States of Southeast Asia."'77

Interestingly, there are several placenames in and around Aceh Besar which are of Indian or Sanskrit origin. The most notable of these are Indrapuri, ${ }^{78}$ on the right bank of the Krueng Aceh (XXII Mukim), Indrapatra at Ladong, east of Banda Aceh (XXVI Mukim), and Indrapurwa in the vicinity of Lambaro (XXV Mukim), a short distance west of Uleelheue and Kuala Cangkoi, the colonial period port of Kuta Raja. ${ }^{79}$ The Krueng Aceh or Aceh river is said to have been once known as the Cedah, a word meaning "lovely." 80 According to Crawfurd, the name Aceh itself derives from a Telinga or Telugu word for a wood leech. 81

Formerly, there was a great mosque (Acehnese: meusegit raya) for each of the three sagi (political divisions) of Aceh which were centered on Indrapuri, Indrapatra, and Intrapurwa. The mosque at Indrapuri is reputedly built upon the foundations of an earlier Hindu Buddhist kuil or temple. The other two mosques have apparently disappeared. Snouk Hurgronje, writing in the early years of this century, noted that "scarcely any trace remains" of the mosques at Indrapatra and Indrapurwa. ${ }^{82}$

In 1977, during a visit to Lambaro and Lambadeuk, Kecamatan Pasar Lambada, west of Banda Aceh, I was informed that the foundations of an ancient mosque were still visible beneath the waves of the bay of Lhok Lambaro. Until recently, I was unable to verify this statement. In mid-1986, however, I examined an aerial photograph of Lambaro which revealed certain morphological changes in the area. Whereas in 1978 the year the photograph was taken, the river mouth (Kuala Pancu) at Lambaro was about $160 \mathrm{~m}$. wide, it has now been reduced to some $25 \mathrm{~m}$., and a second, deeper channel, the Kuala Baro, has been cut through the bar a few hundred meters to the west. It seems that tides and currents are continually changing the morphology of the area. But more dramatic

\footnotetext{
${ }^{75}$ See K. F. H. Van Langen, "De inrichting van het Atjehsche Staatsbestuur onder het Sultanaat," BKI 37 (1888): $382-471$.

${ }^{76}$ See L. F. Brakel, "State and Statecraft in 17th. Century Aceh," in Pre-colonial State Systems in Southeast Asia: The Malay Peninsula, Sumatra, Bali-Lombok, South Celebes, ed. Anthony Reid and Lance Castles, Monographs of the Malaysian Branch of the Royal Asiatic Society No. 6 (Kuala Lumpur, 1975), pp. 56-66.

77 Ibid., p. 66.

${ }^{78}$ These are the sites of at least three of the four Royal mosques built by Sultan Iskandar Muda in the early seventeenth century. Brakel suggests that these names may derive from the Hindu notion that the king, or in this case the Sultan, was an incarnation of Indra! He suggests that one (namely that at Indrapuri), was erected on the site of a former temple "as it seems to contain many archaic (Hindu?) features." Ibid., p. 60, n. 16. This would not be surprising. Similar occurrences, legitimizing the new through identification with the spirit of the old are commonplace.

${ }^{79}$ Van Langen, "Inrichting van het Atjehsche Staatsbestuur," p. 386.

$80_{\text {lbid. }}$.

81 John Crawfurd, A Descriptive Dictionary of the Indian Islands \& Adjacent Countries (Kuala Lumpur: Oxford University Press, 1971), p. 2.

${ }^{82}$ C. Snouck Hurgronje, The Acehnese (Leiden: Brill, 1906), p. 82.
} 
natural forces than tides are at work hereabouts. Banda Aceh lies at the northern end of a line marking the Sumatran Fault system which traverses the whole length of the island from Aceh to Lampung. ${ }^{83}$ Northern Sumatra is considered to be tectonically unstable and is seismically active, which accounts for the numerous earth tremors that are felt regularly in the Banda Aceh region. ${ }^{84}$ In addition to indicating changes in the coastline, the aerial photograph also revealed the presence of the rectangular outline of a submerged structure, some $120 \mathrm{~m}$. from the current shoreline and about $450 \mathrm{~m}$. northwest of the rivermouth of Kuala Pancu as it was in 1978. This, and other physical evidence, is sufficient to suggest that not only has the shoreline receded some 150 to 200 $\mathrm{m}$. over the past eighty years (assuming that this submerged structure is, in fact, the former mosque), but it has also sunk at least two to three meters in the same period if one can judge from Snouck Hurgronje's report of earlier this century. Localized tectonic subsidence would, therefore, appear to be dramatically evident at Lambaro. 85

A local informant indicated that the location of the village of Lambaro had been moved three times within living memory, the last time being early in the Japanese occupation when the inhabitants were forcibly removed from the shoreline and resettled at the foot of the surrounding hills. Yet earlier, a settlement is said to have existed in the area between the present beach ridge and Pulau Angkasa (also known as Pulau Tuan), a rapidly eroding islet a short distance offshore. It was, presumably, in this now submerged settlement that the former great mosque was located.

The first suggestion of still-existing evidence of pre-Islamic habitation sites in and around Aceh Besar came in 1984. My colleague Dr. Bruce Harker recovered three sherds of late Sung or Yuan stoneware from among the tambak (fish ponds) in the vicinity of Kutalakseumana. This site, a short distance east of the Kuala Aceh, is known today at the burial place of Syiah Kuala, Abdulrauf al-Singkeli, an eminent Islamic scholar. ${ }^{86}$

In isolation, three sherds, comprising two fragments of Lung Ch'uan (celadon) greenware and a fragment of a Te Hua spurmarked white glazed basin, cannot, of course, be taken as firm evidence of former habitation. They may have been fragments of heirloom pieces brought from elsewhere or have somehow found their way into the now much-disturbed area of the fishponds. 87

In November 1985 I was able, once again, to visit Banda Aceh and avail myself of the opportunity to investigate briefly this same area. Although I did not find any further fragments of late Sung or Yuan ceramic material in the immediate area of Kutalakseumana, I did recover one or two more sherds of Chinese stoneware which appear to be datable to the later fourteenth or fifteenth centuries and others of the sixteenth century.

\footnotetext{
83B. G. N. Page, J. D. Bennett, N. R. Crawfurd, D. McC. Bridge, D. H. Jeffrey, W. Keats, and J. Thaib, "A Review of the Main Structural and Magmatic Features of Northern Sumatra," Journal of the Geological Society 136 (1979): 1-11.

84J. D. Bennett, "Tectonics and Metamorphism of Northern Sumatra," CCCP/SEATAR Workshop on the Sumatran Transect (Prapat, March 1978). I am grateful to Sandy Macfarlane for discussing the nature, occurrence, and identification of such faults.

${ }^{85} \mathrm{~A}$ similar phenomenon appears to have taken place on the site of the carly nineteenth century port of Boga, near Tanjung Tiram in Simalungun, Sumatcra Utara. The former harbor site is now completely flooded at high tide but traces of the piles of former $\mathrm{d}$ wellings and domestic rubbish are still visible at low tide.

86 Abdulrauf al-Singkeli, a native of Singkel in southern Aceh, made the first translation of the Koran into Acehnese. He died in about 1690. I am grateful to Dr. Castles for this information.

87 I have not forgotten the chastening remark of an eminent ceramicist in Singapore, to whom I showed a few sherds from the Deli area in 1971. He warned me that "a few sherds do not make a Malay kingdom, laddie."
} 


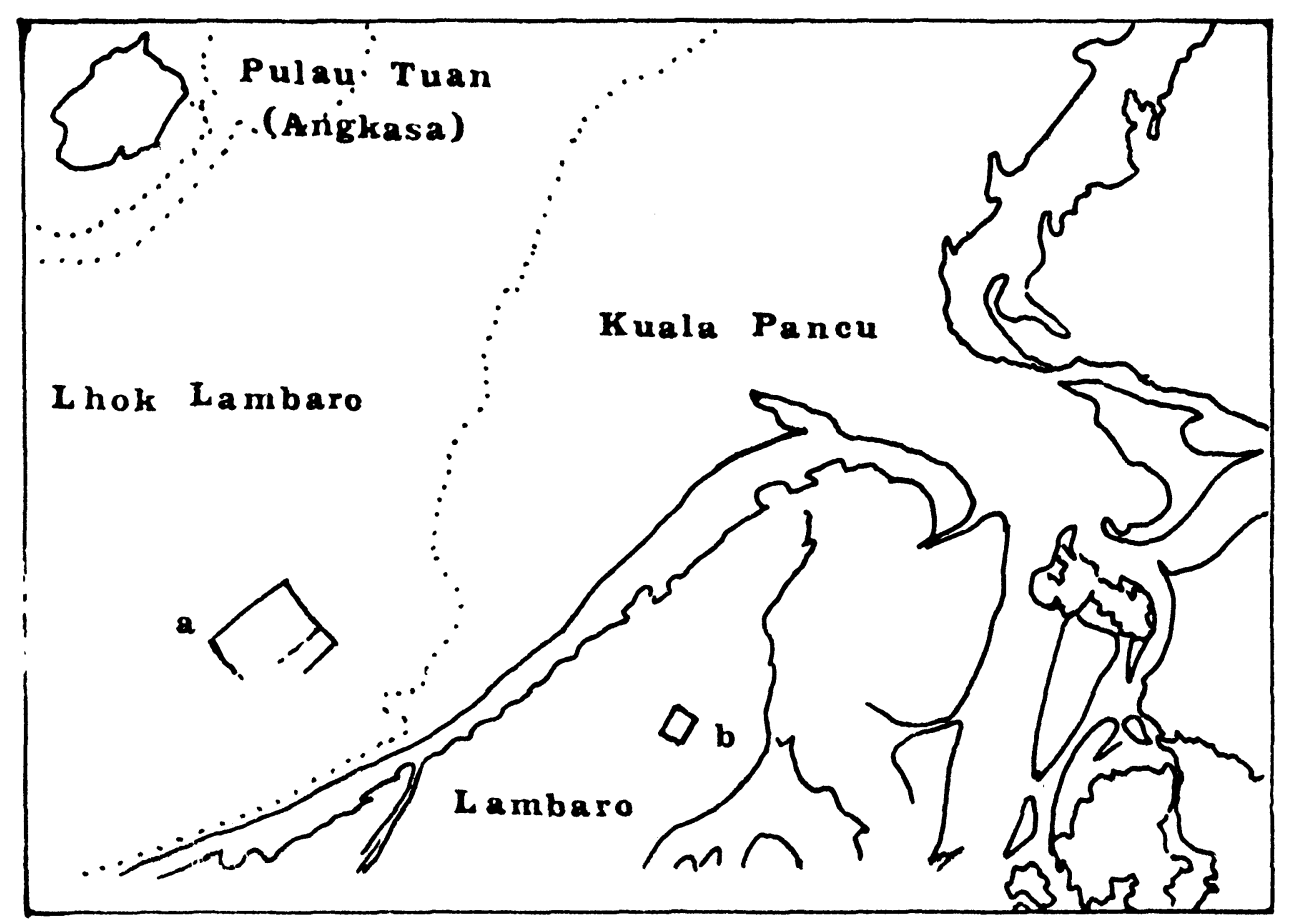

Fig. 3. Lambaro and Kuala Panou (from an aerial photograph dated 1977). a. Submerged rectangular structure.

b. Grave complex (makam). 
More importantly, however, I visited also the foreshore at Lambadeuk and Lambaro to the west of Kuala Cangkoi and Uleelheue. I paid careful attention to the beach ridge, between two small river mouths which allow the sea to flood the mangrove area immediately behind the bay opposite Pulau Angkasa.

Ever since I first visited the area in 1977 and was informed that the foundations of the ancient mosque of Indrapurwa were still visible beneath the sea at low tide, I have suspected that this area might yet conceal other evidence of earlier habitation. At the time of my first visit, however, the tide was in so that it was not possible to see anything of the mudflats or examine the foreshore normally exposed at low tide.

In November 1985 I was able to gain access to the island and the beach ridge between the two channels linking the mudflats with the bay. Behind the beach ridge there were traces of several abandoned dwellings marked by rings of heaped-up coral, the locations of former wells, sherds of pottery and glass, and rusted pieces of iron.

From this area I recovered a rim fragment of a large, late-fifteenth century blue and white Vietnamese basin of excellent quality. The sherd was in good condition and appeared to have been broken only recently. It was in no way subject to corrosion or affected by seawater. Nearer the shore, just below the beach ridge, the receding tide uncovered several fragments of sixteenth century blue and white Ming Chinese stoneware and sherds of local earthenware, all of which were still undamaged by seawater.

Immediately to the west of this location, the low tide revealed a most bizarre sight. Several graves were being gradually washed out by the action of the waves, exposing human skulls and other bones and burial boards. These, according to my informants, probably dated to the eighteenth or nineteenth centuries. Numerous drowned trees littered the foreshore.

Crossing the shallow channel of the Kuala Pancu, the more easterly of the two channels (the westerly one, known as the Kuala Baro is considerably deeper), I found myself treading on fallen nisan (grave markers). 88 On a small headland, some two hundred meters inland and some distance east of the channel, were numerous other Islamic grave markers. Further east again were two parallel rows of river stones, marking graves which are inundated at high water. On the headland, where the tide was gradually eroding topsoil from the back of the beach ridge along the high water mark, I recovered from amongst a scatter of numerous ceramic sherds no less than nine fragments of late Sung or Yuan (thirteenth or fourteenth century) Lung Ch'uan greenware, including a fragment of a two-fish bowl and two sherds of grey-glazed Thai Sawankhalok ware, both from the same vessel. There were also several fragments of copper bronze material, 89 including a rim fragment of a small bowl or cup (estimated diameter approximately 150 $\mathrm{mm}$ ) with an inscription on it, incised in what may be Kufic script both on the rim itself and below the rim, internally and externally, between two parallel lines. ${ }^{90} \mathrm{~A}$ barbed fish

\footnotetext{
${ }^{88}$ As far as I can ascertain without full references at my disposal, J. J. de Vink, in his extensive survey of the Islamic tombstones of eastern and northern Aceh between 1912 and 1917 either did not visit the Lambaro area or did not report any inscribed nisan of particular interest. His reports are available in the Outheidkundige Verslag.

${ }^{89}$ Interestingly, Gerini, quoting Hirth's translation of Odoric, indicates that in the early fourteenth century, "Household vessels (in Lambri) are made of bronze." Gerini, Researches, p. 680.

90 Further expert opinion is required to try to ascertain the script exactly. It may be entirely decorative, as the letters do not appear to form actual words. Since finding this fragment, I have seen a modern brass bowl entirely decorated in Islamic script which, I understand, is thought to have come from Gujerat.
} 
hook, two small pieces of wire, part of a square nail, and several small rectangular plates, also of bronze, were recovered at the same spot adjacent to a rectangle measuring approximately $3 \times 4$ meters marked out by river stones that would appear to have formed the outline of the floor of a small hut or dwelling. Also in the immediate vicinity of this outline were numerous sherds of sixteenth century Chinese stonewares and later porcelain sherds of Chinese and European origin, together with other rubbish including quantities of broken glass of apparently twentieth century origin. What could not be ascertained at the time was whether or not the sherd deposits represent direct accumulations of cultural remains or whether they are the results of redeposition due to riverine or tidal action. Whatever the effect of water action upon the deposits, the fact remains that the sherds and other artifacts are unlikely to have been deposited from outside the Lambaro area.

After an interval of some ten months, I was again able to visit Lhok Lambaro and confirm the indications of my earlier finds. Some 250 to 300 meters east of the present site of the Kuala Pancu lie two submerged groups of what appear to be stone foundations that are currently visible at low water. These are not visible on the aerial photographs taken in 1978.91

The most easterly foundation is rectangular in outline and measures some fifty meters from east to west and about thirty meters from north to south. It is exposed at low tide. A short distance to the west of this structure is what appears to be a group of somewhat scattered rectangular foundations, possibly the sites of dwelling houses which are also visible at low tide.

A few sherds of Chinese late Sung or Yuan, Ming, and Ch'ing porcellaneous stonewares have been recovered from this area, 92 but as the whole beach at this point is covered in fine sand, other cultural materials may well be buried beneath the surface. Inland of this point, on the Kuala Pancu, on the same eroding headland that I had visited previously, I recovered additional late Sung, Yuan, Ming, Thai, and European sherds, datable ceramics which cover a span of some seven centuries.

West of Kuala Pancu, I have not been able to confirm the location of the structure depicted on the 1978 aerial photographs. During my last visit to the area, the water in this part of the bay was extremely murky, making it impossible to see what lies beneath the surface. Although there are what appear to be coral heads in the area, it was not possible to identify the remains of any stone structures.

The beach and eroding beach ridge immediately landward of this area has, however, yielded a number of additional finds. Further fragments of Thai Sawankhalok ware, the base of a Burmese (Pegu) ware white glazed jar with painted decoration, and other Vietnamese wares, fragments of later (Ming and $\mathrm{Ch}^{\prime}$ ing) Chinese stonewares, and local earthenware were also recovered. Also included were sizeable parts of two spouted earthenware lamps of traditional Acehnese design and part of a large wafer-like brick of a

\footnotetext{
91 I am grateful to Dr. Bruce Harker for this information and for showing me the location. Dr. Harker suggests that a severe storm in late 1985 may have been responsible for uncovering the remains now visible east of the Kuala Pancu.

92 I am indebted to Mrs. Janet Donald who kindly allowed me to examine and photograph the sherds that she collected from this vicinity in May 1986. They include fragments of late Sung/Yuan period Chekiang greenware and part of a contemporary Te Hua covered box, together with fragments of Chinese blue and white ware of the seventeenth and eighteenth centuries and Thai Sawankhalok ware.
} 
type common in the Majapahit era, 93 an iron cannon ball approximately eight centimeters in diameter and numerous bovine bones and teeth.

\section{Conclusions}

These surface finds, and the ceramic recoveries in particular, suggest a continuity of habitation of the Lambaro area from at least the thirteenth or fourteenth centuries through to the recent past, a span of some seven centuries. ${ }^{94}$ Excavations, even of the rapidly dug test pit variety could no doubt confirm the existence of further accumulations of domestic rubbish which might shed more light on the nature of the settlement.

Geological instability, due to localized tectonic subsidence, particularly in the bay of Lhok Lambaro itself, could account for the virtual disappearance of the Lambaro site 95 which tradition associates with ancient Indrapurwa. In the circumstances, it would appear that much, though not all, of the site of ancient Lambri may be irretrievably lost under the sea. The same may also be true of an early settlement in the region of Ladong (Indrapatra), east of the Krueng Aceh and also at Krueng Raya.

The evidence of surface finds at Lambaro is sufficient to confirm the existence of a coastal settlement in the region associated with the toponym Lambri during a large part of the period covered by the historical record. It would appear reasonable to conclude that Lambaro may thus be associated with the toponym known to Arab, Chinese, and Indian sources as Lambri, even though there may have been other contemporary sites along this coast. The name "Lambaro" itself, meaning the new lam, is suggestive of continuity of occupation, especially when related to the local tradition of an older settlement at the site. The name is also recognizably similar to Lambri whereas, paradoxically, neither Krueng Raya, Teuku Iskandar's alternative candidate, nor Ladong could fit.

The identification of Lambaro as Lambri would also possibly resolve a problem relating to Chia Tan's description of P'o-lu which Professor Wolters equates with Ramni (above). A comment in the Hsin T'ang shu regarding the erection at P'o-lu of a sundial post, eight ch'ih in height at the summer solstice, giving a shadow lying to the south of the post two ch'ih and five t'sun long, is fitting in relation to Lambaro. Gerini understood this comment to refer to the northernmost limit of the land of Srivijaya and calculated it to be $5^{\circ} 50^{\prime} \mathrm{N}$ (plus or minus an error of $20^{\prime}$ )..$^{96}$

The archaeological site at Lambaro is situated on the Kuala Pancu. As both Lambaro and Pancu are thus virtually one and the same geographical location, $5^{\circ} 41^{\prime} \mathrm{N}, 95^{\circ} 03^{\prime} \mathrm{E}$, well within the limit of error calculated by Gerini, the inference is that $P^{\prime} 0-l u$, Ramni, and Lambri are indeed one and the same.

\footnotetext{
${ }^{93} \mathrm{Dr}$. Pierre-Yves Manguin informs me that he found similar bricks at a keramat site on Pulau Angkasa in Lhok Lambaro.

94 Some years ago, Mr. Lim Chi, an antique dealer in Medan, had for sale a Roman copper coin of the emperor Hadrian which, he said, came from Aceh. Unfortunately he was unable to give any precise details of where the coin had been found. One wonders if one may expect much earlier finds in the Lambaro area? Something of the nature of a Sumatran Oc-Eo is perhaps not beyond the bounds of credibility.

95 Interestingly, Gerini, in discussing the location of Lambri mentions Lambarih on the left bank of the Krueng Aceh and Lambaro just below it (a different Lambaro). He dismisses the latter as the name means "new village." See Gerini, Researches, p. 664.

96 Ibid., pp. 482-83.
} 


\section{Suggestions for Further Research}

Considering the evidence given above, further research in the Lambaro area would appear to be justified. Four basic lines of research might be undertaken in northern Aceh. These are:

1. Utilization of large scale aerial photography to study the coast between Ujung Masam Muka (Aceh Head) and Krueng Raya, paying particular attention to the area of Lhok Lambaro (Indrapurwa) and that of Ladong (Indrapatna) for signs of submerged structures along the shoreline.

2. Utilization of side-looking radar to identify local faulting and tectonic subsidence to ascertain the extent of such subsidence.

3. Intensive survey at, and behind, the shoreline at Lambaro, Krueng Aceh, Ladong, and Krueng Raya to try to identify traces of earlier habitation, followed by appropriate excavation at any potential sites identified in the course of surveys.

4. Submarine surveys, by means of scuba or snorkeling techniques in any areas of submerged structures identified under 1 above. 